\title{
Editorial: On Curriculum Philosophy, Thinking, and Theorising in South African Higher Education Transformation
}

\author{
Petro du Preez \\ ORCID iD: https://orcid.org/0000-0002-9100-6461
}

Labby Ramrathan

ORCID iD: https://orcid.org/0000-0001-9963-0675

\section{Shan Simmonds}

ORCID iD: https://orcid.org/0000-0001-5005-9906

\section{Introduction}

Transformation in South African higher education has been an on-going process since the mid-1990s, focusing initially on the demographic profiles of staff and students, through to widening physical access, and making attempts to improve student throughput and graduation rates (Du Preez et al. 2016). Although matters curricula were part of the transformation movement, they were addressed, in most cases, as part of a proliferation of policies geared toward addressing structural aspects dealing with the exoskeleton of the curriculum (Lange 2017) but a more nuanced look at curriculum is needed. This has been initiated through published works such as Bitzer and Botha (2011) and Samuel et al. (2016). But the complexities and pressures of an emerging fourth industrial revolution, the mobility of students, the rapid growth in technologies, the environmental crisis, the widening inequalities of epistemological access, and calls for decolonisation inform key discourses that are shifting our thinking about higher education curriculum (Jansen 2019; Le Grange et al. 2020). Juxtaposed against these complexities and pressures, 
curriculum transformation is further complicated by the COVID-19 pandemic that has led to the investigation of the posthuman in education and in the lives and livelihoods of people across the globe in an ecology that includes humans and other biological and environmental elements (Ramrathan et al. 2020). These key discourses revolve around the sorely needed troubling of the curriculum so as to enable alternative pathways for its advancement.

Initiated by members of the South African Education Research Association curriculum studies special interest group, this special issue's intent is to engage critically with various dimensions of curriculum transformation. This important, appropriate, and timely scholarly undertaking with its philosophical and theoretical musings, is framed by the questions: Why is curriculum philosophy, thinking, and theorising in South African higher education transformation pivotal right now? How has curriculum transformation unfolded in diverse higher education institutions? These questions are central to curriculum specialists and their continued commitment to advance the field in South Africa. Articles providing philosophical engagement with higher education curriculum transformation open this special issue and these are followed by articles that contribute to the thinking and theorising thereof.

\section{Philosophical Engagements with Higher Education Curriculum Transformation}

'Higher Education Curriculum Transformation in and of Radical Immanence: Towards a Free and Creative Ethics' shows how curriculum transformation experienced thus far reinforces a reductionist approach to transformation that is fundamentally transcendentally motivated and, therefore, tends to overlook education as meaningful in and of itself. Using Deleuze's notion of radical immanence in relation to discourses of higher education curriculum transformation, the authors of this paper argue that this transformation needs to be complemented by other notions of immanence so as to open up avenues for a new kind of ethics.

'(Re)Thinking Lived Curriculum as Complicated Conversation through Nomadic Thought in Pursuit of Curriculum Transformation' invites deep reflection on the discontent evident in South African higher education regarding the critique and dismantling of dominant inscriptions of curriculum. 


\section{Editorial}

In an attempt to engender a curriculum discourse that shifts the focus from policy to the subject, this article engages with subjectivity and the lived curriculum as a constructive tensionality. In a (re)thinking of lived curriculum as complicated conversation, the author takes account of the posthuman era and uses this to unlock the possibilities of complicated conversation through nomadic thought.

'Towards an Embodied Critical Pedagogy of Discomfort as a Decolonising Teaching Strategy' focuses on a humanising critical pedagogy of discomfort to practice social justice though curriculum. Through a discussion of students' responses to racism, privilege, and inequality as experienced in South Africa and in its university classrooms, the authors advocate for a shift towards an 'embodied critical pedagogy of discomfort'. This kind of pedagogy takes into account the acute awareness (epistemological and ontological) of embodiment in its desire to counteract education that promotes instrumentalization and commodification in favour of cultivating social justice as a form of decolonisation.

Continuing with issues of inequality and social injustice, 'The (Post)human Condition and Decoloniality: Rethinking and Doing Curriculum' brings to the fore the significance of the (post)human awareness that valuing all of life and its interconnectedness should characterise our very being in this 21 st century context. The article raises critical existential and educational questions such as: How should we live? What is the unit of reference for the human now? How should we learn? What knowledge is of most worth? Whose knowledge is of most worth? Through the insightful analysis of the implications of these questions, the notion of curerre-ubuntu is introduced as a concept for reimagining curriculum in the post-Anthropocene.

\section{Thinking and Theorising Higher Education Curriculum Transformation}

Bringing into dialogue the Anthropocene and the current COVID-19 complexities, 'Curriculum Theorising in an Economics Education Programme' explores border thinking as a tool to unpack curriculum theorising historically in the Economics education curriculum. Using Decolonial Critique and Posthumanism, this paper explores how canonical thought on, and principles of, Economics might be disrupted in a teacher education programme for preservice teachers of Economics. The centrality of human need satisfaction is 
troubled to reflect on the application of a disruptive curriculum to contest traditional disciplinary Economics knowledge.

The issue of inequality is again brought to the fore in 'A Reflection on Academisation and its Effect on Curriculum Transformation in South Africa's Higher Education Sector' that provides a critical reflection on academisation as one of the educational discourses in higher education determining transformation of the curriculum. This paper provokes responses to curriculum transformation as an academisation process by asking: Does the curriculum strive for inclusion of the narratives of all stakeholders? Does it strive for the creation or development of students who can be regarded as socially responsive citizens with well-developed critical thinking skills?

Extending the notion of curriculum for relevance, 'Using Translanguaging in Higher Education to Empower Students' Voices and Enable Epistemological Access' centres the voices of students in their construction of an academic identity with a focus on plurilingualism and translanguaging. In this paper the authors make a case for a sense of embodied self, an active element in the formation of geo- and body-politics of knowledge which has been highlighted in recent literature focussing on translanguaging in education and decolonising the curricula of higher education.

Given the guiding questions informing this publication, these papers all allude to the importance of placing emphasis on the philosophical underpinning of curriculum transformation to shift the discourses from those that favour an instrumental approach to those that offer a more philosophical one. The reason behind this need lies in the diverse complexities that feed into it; all of them demand curriculum transformation in higher education and in schools.

\section{References}

Bitzer, E. \& N. Botha. 2011. Curriculum Inquiry in South African Higher Education: Scholarly Affirmations and Challenges. Stellenbosch: SunMedia Publishers.

Du Preez, P., S. Simmonds \& A. Verhoef. 2016. Rethinking and Researching Transformation in Higher Education: A Meta-study of South African Trends. Transformation in Higher Education 1, 1: 1-7.

https://doi.org/10.4102/the.v1i1.2 


\section{Editorial}

Jansen, J. 2019. Decolonisation in Universities: The Politics of Knowledge. Johannesburg: Wits University Press.

https://doi.org/10.18772/22019083351

Lange, L. 2017. 20 Years of Higher Education Curriculum Policy in South Africa. Journal of Education 68: 31-57.

Le Grange, L., Du Preez, P., Ramrathan, L. \& Blignaut, S. 2020. Decolonising the higher education curriculum: A multiple case study. Journal of Education 80, forthcoming.

Ramrathan, L., N. Ndimande-Hlongwa, N. Mkhize \& J.A. Smit. 2020. Rethinking the Humanities Curriculum in the Time of COVID-19. Pietermaritzburg: CSSALL Publishers.

Samuel, M.A., R. Dhunpath \& N. Amin. 2016. Disrupting Higher Education Curriculum: Undoing Cognitive Damage. Rotterdam: Sense. https://doi.org/10.1007/978-94-6300-896-9

Petro du Preez Professor School of Professional Studies in Education

North-West University

Potchefstroom petro.dupreez@nwu.ac.za

Labby Ramrathan Professor

Department

University of KwaZulu-Natal

Durban

RAMRATHANP@ukzn.ac.za

Shan Simmonds

Professor

Department of Curriculum Studies

North-West University

Potchefstroom

shan.simmonds@nwu.ac.za 